\title{
Oxidation of Alloys in Controlled Atmospheres
}

Taketomo YAMAZAKI*

Key Words : Controlled Atmospheres, Transient Oxidation, Selective Oxidation, Internal Oxidation, Steady-State Oxidation

制御举囲気熱処理の基礎として，最近の合金の酸化に 関する理論と $\mathrm{H}_{2}-\mathrm{H}_{2} \mathrm{O}$ 䨌囲気におけるCr-Fe, Cr-Ni合 金の酸化 $\left(\mathrm{Cr}_{2} \mathrm{O}_{3}\right.$ 生成)の熱力学を記述し, 合金の酸化の 代表的な事例を示した。特に，遷移酸化の機構および内 部酸化から外部酸化への移行におよぼす合金組成と酸化 条件すなわち雾囲気の酸素分圧と温度の影暃を明らかに した。さらに, 酸化皮膜の組成分布を理論的, 実験的視 点から記した。

\section{1. 緒 $\overline{\bar{D}}$}

金属・合金の制御雾囲気における酸化は光輝焼なまし (BA之略称), 浸炭, 浸硫, および酸窒化などの基礎と して重要であり多くの研究者によって研究が行われてい る。特に, BAに関しては基礎的研究が1910年ごろから 盛んに行われ，これまでに数多くの成果が報告されてき た $^{1) \sim 9}$ 。さらに今日では界面分析の手法が著しく進展 ${ }^{10)}$ したため表面の結晶構造や組成などの情報が詳細に得ら れるようになった。BAや浸炭などの無酸化加熱や表面 改質の技術は高温度の特別に制御した組成雾讲気で金属・

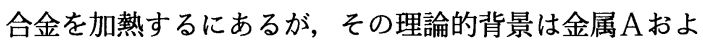
び合金 $\mathrm{AB}$ の溶媒元素 $\mathrm{A}$ （溶質元素を $\mathrm{B}$ とする）を酸化 させずに加熱するにあり，技術的には気体雾囲気（単に 雾囲気と記す）の酸素分圧を $\mathrm{AO}$ 酸化物の平衡酸素解離 圧以下に制御して金属・合金を加熱するにある。制御雾 囲気における酸化の特徴は外部酸化, 内部酸化および粒 界酸化の各層が個別にあるいは混り合って生成されるこ とであり，これらと合金の組成と物性, 生成される酸化 物の物性と析出挙動との関係が重要である。

本稿では, 金属は単一組成であるからここでは合金に 限り，最近の雾囲気制御之制御した雾同気における金属・ 合金の酸化について記述し，また実用的に多く使われて いる $\mathrm{Cr}-\mathrm{Fe}, \mathrm{Cr}-\mathrm{Ni}$ 合金について主として述べること にする。また，雾囲気の組成も酸化性成分ガスにはイオ

* 鶴岡工業高等専門学校（二997 山形県鶴岡市大字井岡字沢田 104)

Tsuruoka College of Tech. (104, Sawada Inooka, Tsuruoka-shi, Yamagata 997)
ウ，八ロゲンなどあ含まれるが，ここでは酸素に限定す る。

\section{2. 弱酸化性雾囲気の制御}

BAのような低酸素分圧の需囲気で行う熱処理は，通 常, 低露点の $\mathrm{H}_{2}$ あるいは $\mathrm{H}_{2}-\mathrm{N}_{2}$ 混合雾囲気中で行われ る。浸炭を行うときはCO- $\mathrm{CO}_{2}$ あるいは $\mathrm{CH}_{4}-\mathrm{H}_{2}$ 混合雾 用気を使用するが, 前者は $\mathrm{CO}$ と $\mathrm{CO}_{2}$ とを調整すると $\mathrm{H}_{2}-\mathrm{H}_{2} \mathrm{O}$ と同じように無酸化加熱に応用できる。それは 次のように求められる。

$$
\begin{aligned}
& \left(\mathrm{H}_{2}\right)+1 / 2\left(\mathrm{O}_{2}\right)=\left(\mathrm{H}_{2} \mathrm{O}\right) \\
& (\mathrm{CO})+1 / 2\left(\mathrm{O}_{2}\right)=\left(\mathrm{CO}_{2}\right)
\end{aligned}
$$

(1)と(2)式の質量作用の法則から, 平衡定数, $K_{\mathrm{P}}$ は, そ れぞれ,

$$
\begin{aligned}
& K_{\mathrm{P}(1)}=P_{\mathrm{H}_{2} \mathrm{O}} / P_{\mathrm{H}_{2}} P_{\mathrm{O}_{2}}^{1 / 2} \\
& K_{\mathrm{P}(2)}=P_{\mathrm{CO}_{2}} / P_{\mathrm{CO}} P_{\mathrm{O}_{2}}^{1 / 2}
\end{aligned}
$$
であたえられる。

ここに, 例えば, $\mathrm{H}_{2}-\mathrm{H}_{2} \mathrm{O}$ 混合雾囲気の場合は, $P_{\mathrm{H}_{2} \mathrm{O}}, \mathrm{P}_{\mathrm{H}_{2}}, P_{\mathrm{O}_{2}}$ は, 雾囲気ガス成分 $\mathrm{H}_{2} \mathrm{O}, \mathrm{H}_{2}, \mathrm{O}_{2}$ の分 圧で, 同雳囲気の各ガス成分のモル数, モル分率をそれ ぞれ, $n_{\mathrm{H}_{2} \mathrm{O}}, n_{\mathrm{H}_{2}}, n_{\mathrm{O}_{2}}, x_{\mathrm{H}_{2} \mathrm{O}}, x_{\mathrm{H}_{2}}, x_{\mathrm{O}_{2}}$ とすると,

$$
\left.\begin{array}{l}
P_{\mathrm{H}_{2} \mathrm{O}}=x_{\mathrm{H}_{2} \mathrm{O}} \mathrm{O}, \quad x_{\mathrm{H}_{2} \mathrm{O}}=n_{\mathrm{H}_{2} \mathrm{O}} /\left(n_{\mathrm{H}_{2} \mathrm{O}}+n_{\mathrm{H}_{2}}+n_{\mathrm{O}_{2}}\right) \\
P_{\mathrm{H}_{2}}=x_{\mathrm{H}_{2}} P, \quad x_{\mathrm{H}_{2}}=n_{\mathrm{H}_{2}} /\left(n_{\mathrm{H}_{2} \mathrm{O}}+n_{\mathrm{H}_{2}}+n_{\mathrm{O}_{2}}\right) \\
P_{\mathrm{O}_{2}}=x_{\mathrm{O}_{2}} P, \quad x_{\mathrm{O}_{2}}=n_{\mathrm{O}_{2}} /\left(n_{\mathrm{H}_{2} \mathrm{O}}+n_{\mathrm{H}_{2}}+n_{\mathrm{O}_{2}}\right)
\end{array}\right\}
$$

である。Pは全圧で, 通常 $1 \mathrm{~atm}(101.32 \mathrm{kPa})$ である。 さらに, 酸素分圧を制御するために不活性ガス $i$ を添加 する場合は, 当然のことながら(5)式に, Piの項が加わ る。

熱力学的には, $K_{\mathrm{P}}$ と標準自由エネルギー $\left(\Delta G_{\mathrm{T}}^{\circ}\right)$ と の関係は,

$$
\Delta G^{\circ}{ }_{\mathrm{T}}=-R T \ln K_{\mathrm{P}}
$$

であるから上記二式の $P_{\mathrm{o}_{2}}$ はそれぞれ次のように与えら れる。

$$
\begin{aligned}
P_{\mathrm{O}_{2}(1)} & =\left(P_{\mathrm{H}_{2} \mathrm{O}} / P_{\mathrm{H}_{2}}\right)^{2} K_{\mathrm{P}(1)}^{-2} \\
& =\left(P_{\mathrm{H}_{2} \mathrm{O}} / P_{\mathrm{H}_{2}}\right)^{2} \exp \left(2 \Delta G_{\mathrm{T}(1)}^{\circ} / R T\right) \cdots \cdots(7) \\
P_{\mathrm{O}_{2}(2)} & =\left(P_{\mathrm{CO}_{2}} / P_{\mathrm{CO}}\right)^{2} K_{\mathrm{P}(2)}^{-2} \\
& =\left(P_{\mathrm{CO}_{2}} / P_{\mathrm{CO}}\right)^{2} \exp \left(2 \Delta G_{\mathrm{T}(2)}^{\circ} / R T\right) \cdots \cdots(8)
\end{aligned}
$$


また，これら(1)と(2)式の標準自由エネルギーは, それぞ れ次のように与えられているから,

$$
\Delta G^{\circ}{ }^{\mathrm{T}(1)}=-56925-8.73 T-2.93 T \ln T
$$$$
-0.64 \times 10^{-3} T^{2}-0.08 \times 10^{5} T^{-1}
$$

$\Delta G_{\mathrm{T}(2)}^{\circ}=-68328.62+23.15 T-0.18 T \cdot \ln T$

$-0.64 \times 10^{-3} T^{2}+0.865 \times 10^{5} T^{-1}$

(7) (10)式を使って $\mathrm{H}_{2}-\mathrm{H}_{2} \mathrm{O}, \mathrm{CO}-\mathrm{CO}_{2}$ 雾囲気の酸素分 圧が求められる。

$\mathrm{H}_{2}-\mathrm{H}_{2} \mathrm{O}-\mathrm{CO}-\mathrm{CO}_{2}$ の混合雾囲気の酸素分圧は, $P_{\mathrm{O}_{2}}$ が 一定であるから,

$$
\left(P_{\mathrm{H}_{2} \mathrm{O}} / P_{\mathrm{H}_{2}}\right)\left(P_{\mathrm{CO}} / P_{\mathrm{CO}_{2}}\right)=\left(K_{\mathrm{P}(1)} / K_{\mathrm{P}(2)}\right)
$$

によってそれぞれ雾囲気成分の分圧が求められる。

以上のことから明らかなように，(7)から(11)式を用いて 求められる $\mathrm{P}_{2}$ は雾囲気の酸化能を表わすので, この酸 素分圧を酸素ポテンシャルという。この值が表面に生成 された酸化物の平衡酸素解離圧より大きいと酸化は引き 続き進行し，この酸素ポテンシャルに応じてより高級な 酸化物が生成される。

\section{3. 酸化物の平衡酸素解離圧}

はじめに，金属クロム， $\mathrm{Cr} ，$ の酸化を考える。 $\mathrm{Cr}$ の 酸化物は純粋な $\mathrm{Cr}_{2} \mathrm{O}_{3}$ だけであって次式によって反応は 進行し,

$$
\left\langle\mathrm{Cr}_{2} \mathrm{O}_{3}\right\rangle=2\langle\mathrm{Cr}\rangle+3 / 2\left(\mathrm{O}_{2}\right)
$$

$\mathrm{Cr}_{2} \mathrm{O}_{3}, \mathrm{Cr}$ および $\mathrm{O}_{2}$ の反応平衡が成立する。反応平 衡が成立するためには，それぞれの部分モル自由エネル ギー（化学ポテンシャル） $\bar{G}_{\mathrm{i}}$ が,

$$
\bar{G}_{\mathrm{Cr}_{2} \mathrm{O}_{3}}=2 \bar{G}_{\mathrm{Cr}}+3 / 2 \bar{G}_{\mathrm{O}_{2}}
$$

でなければならない党，12), ${ }^{13)}$ 。 $\mathrm{Cr}$ と $\mathrm{Cr}_{2} \mathrm{O}_{3}$ は純粋系と仮 定したのであるから，これらの $\bar{G}_{\mathrm{Cr}}$ および $\bar{G}_{\mathrm{Cr}_{2} \mathrm{O}_{3}}$ は $G^{\circ}{ }_{\mathrm{Cr}}$ お よび $G_{\mathrm{Cr}_{2} \mathrm{O}_{3}}$ に等しく, $\bar{G}_{\mathrm{O}_{2}}$ は

$$
\bar{G}_{\mathrm{O}_{2}}=G_{\mathrm{O}_{2}}^{\circ}+R T \ln P_{\mathrm{O}_{2}(\mathrm{eq} \cdot \mathrm{T})}^{\circ}
$$

であるから(13)式は

$$
G_{\mathrm{Cr}_{2} \mathrm{O}_{3}}^{\circ}=2 G_{\mathrm{Cr}}^{\circ}+3\left(G_{\mathrm{O}_{2}}^{\circ}+R T \ln P_{{ }_{\mathrm{O}_{2}} \text { (eg.T) }}^{\circ}\right) / 2 \cdots(15)
$$

のように与えられる。GはTのみに依存するから, 温度 $T$ では唯一の酸素分圧 $P^{\circ}{ }_{{ }_{2}(\text { eq. T) }}$ が存在し, この系は平衡 が成立する。 $P^{\circ}{ }_{\mathrm{O}_{2} \text { (eq.T) }}$ は次のように与えられる。

$$
P^{\circ}{ }_{\mathrm{O}_{2} \text { (eq.T) }}=\exp \left\{2\left(G_{\mathrm{Cr}_{2} \mathrm{O}_{3}}^{\circ}-G^{\circ}{ }_{\mathrm{Cr}}-3 / 2 G_{\mathrm{O}_{2}}^{\circ}\right) / 3 R T\right\}
$$

同様に, Fe合金その他Ni合金などについても，それ らの酸化物の平衡酸素解離圧を求めることができる。平 衡酸素解離圧は温度によって定まるから, Cr-O, Fe-O, $\mathrm{Fe}-\mathrm{M}-\mathrm{O}$ 系(MはCr, $\mathrm{Mn}, \mathrm{Al}, \mathrm{Ni}$ な゙)などの $\mathrm{P}_{\mathrm{o}_{2}}-T$ の関係が求められる。

$\mathrm{Cr}-\mathrm{Fe}$ 合金の酸化では,

$$
\begin{aligned}
& \left\langle\mathrm{Cr}_{2} \mathrm{O}_{3}\right\rangle=2\{\mathrm{Cr}\}+3 / 2\left(\mathrm{O}_{2}\right) \\
& \left\langle\mathrm{FeCr}_{2} \mathrm{O}_{4}\right\rangle=\{\mathrm{Fe}\}+2\{\mathrm{Cr}\}+2\left(\mathrm{O}_{2}\right) \cdots \cdots \cdots \cdot(18) \\
& \left\langle\mathrm{FeCr}_{2} \mathrm{O}_{4}\right\rangle=\{\mathrm{Fe}\}+\left\langle\mathrm{Cr}_{2} \mathrm{O}_{3}\right\rangle+1 / 2\left(\mathrm{O}_{2}\right) \cdots(19)
\end{aligned}
$$

ここで, \{ \},（）あるいはく〉は化学平衡にある成分 の相の区別を表わし，それぞれ合金（固相溶液一固溶 体), 気体，あるいは固体の各相を意味する。すなわち, (17)式はCr-Fe合金のクロム, $\{\mathrm{Cr}\}$, が気体酸素, $\left(\mathrm{O}_{2}\right)$, と反応して純粋の固体の $\left\langle\mathrm{Cr}_{2} \mathrm{O}_{3}\right\rangle$ を生成することを示 す。 $\mathrm{Cr}$ はCr-Fe合金の溶液成分（活量, $a_{\mathrm{cr}}, 18 \% \mathrm{Cr}-\mathrm{Fe}$ であると $\left.a_{\mathrm{Cr}}=0.33^{14)}\right)$ であるから, それが平衡状態にあ ると, (17)式は,

$$
G_{\mathrm{Cr}_{2} \mathrm{O}_{3}}^{\circ}=2 \bar{G}_{\mathrm{Cr}}+3 / 2 \bar{G}_{\mathrm{O}_{2}}
$$

ここに, $\bar{G}_{\mathrm{Cr}}$ はFe-Cr合金のCrの化学ポテンシャルで ある。それゆえ,

$$
\bar{G}_{\mathrm{Cr}}=G_{\mathrm{Cr}}^{\circ}+R T \ln a_{\mathrm{Cr}}
$$

である。（17)式を標準生成自由エネルギーで表わすと,

$$
\begin{aligned}
G_{\mathrm{Cr}_{2} \mathrm{O}_{3}}^{\circ}= & 2 G_{\mathrm{Cr}}^{\circ}+2 R T \ln a_{\mathrm{Cr}}+ \\
& 3\left(G_{\mathrm{O}_{2}}^{\circ}+R T \ln P_{\mathrm{O}_{2} \text { (eq.T) }}^{\circ}\right) / 2
\end{aligned}
$$

となり，与えられた $a_{\mathrm{cr}}$ に対しては，(17)式とは異なる $P^{\prime}{ }_{\mathrm{O}_{2} \text { (eq.T) }}$ が存在する。

(16)式を用いて(22)式を整理すると,

$$
P_{\mathrm{O}_{2} \text { (eq.T) }}^{\prime}=P_{\mathrm{O}_{2} \text { (eq.T) }}^{\circ} \cdot a_{\mathrm{Cr}}{ }^{-4 / 3} \text {. }
$$

が得られる。

(23)式はCr-Fe合金が酸素, $\mathrm{O}_{2}$, と反応して $\mathrm{Cr}_{2} \mathrm{O}_{3}$ を 生成するときの一定温度における酸化性雾囲気の酸素ポ テンシャルと $\mathrm{Cr}$ 濃度 $\left(a_{\mathrm{Cr}}\right.$ または原子分率 $\left.x_{\mathrm{Cr}}\right)$ との関係 を表わす。これと同様の手順で $\mathrm{FeCr}_{2} \mathrm{O}_{4}$ などについて あ求めることができる。このようにして, Fe-Cr-O系 状態図の $\Delta G^{\circ}{ }_{\mathrm{T}}-T$ 図 ( $x_{\mathrm{i}}$ 一定), $P_{\mathrm{O}_{2}}-T$ 図 ( $x_{\mathrm{i}}$ 一定), $x_{\mathrm{i}}-T$ 図( $P_{\mathrm{O}_{2}}$ 一定 $), P_{\mathrm{O}_{2}}-x_{\mathrm{i}}$ 図( $T$ 一定)が得られる。こ れらの図はスケールの酸化物相組成を推定するうえにも 重要である。図 1 はPelton ら ${ }^{15)}$ が行ったFe-Cr-O系 の $\log P_{\mathrm{O}_{2}}=-21$ における $x_{\mathrm{cr}}-T$ 図のコンピュータ支

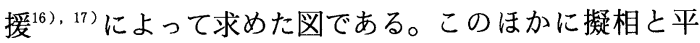
衡する雲囲気の組成を原子分率で表示する図がGurry ${ }^{18)}$ およびLittlewood ${ }^{19)}$ によって提出されている。これは

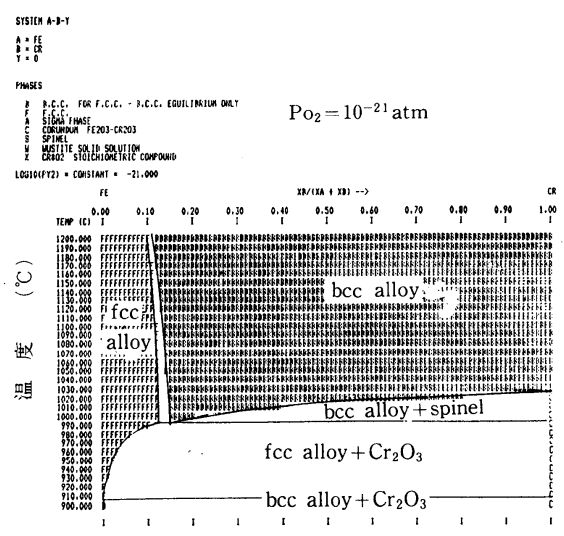

図 1 Fe-Cr-O系状態図 (コンピュータ計算図), $P_{\mathrm{O}_{2}}=1.01 \times$ $10^{-16} \mathrm{~Pa}\left(10^{-21} \mathrm{~atm}\right.$ ) (文献 15,16 ) 


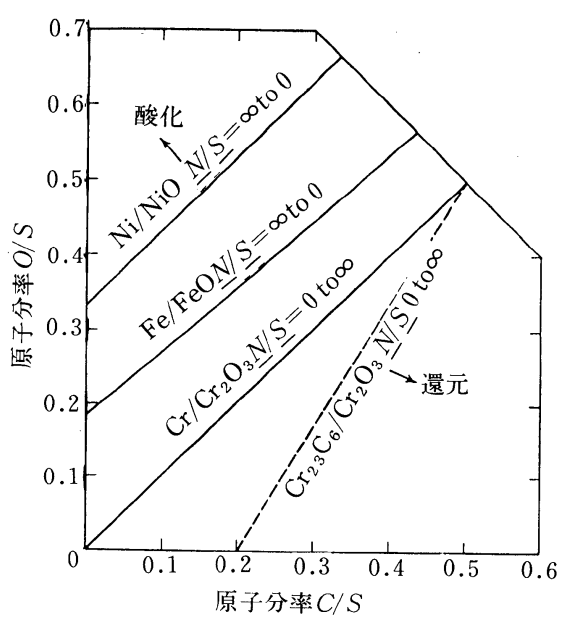

図 $2 \mathrm{Ni}, \mathrm{Fe}, \mathrm{Cr}$ およびその酸化物と平衡する雾囲気の組成, 1323K.（Gurry図)（文献19）

雾囲気組成の主成分である $\mathrm{CO}, \mathrm{CO}_{2}, \mathrm{H}_{2}, \mathrm{H}_{2} \mathrm{O}$ および $\mathrm{CH}_{4}$ から原子モル分率である $\overline{\mathrm{C}}, \overline{\mathrm{H}}$ およびত̄ 和 $\overline{\mathrm{C}}+\overline{\mathrm{H}}+\overline{\mathrm{O}}=\overline{\mathrm{S}}$ で除した值を $\mathrm{x} ， \mathrm{y}$ 軸として表示するす

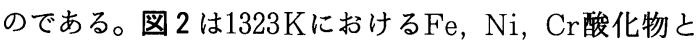
平衡する雾囲気組成のGurry 図 ${ }^{19)}$ である。ここに,

$$
\begin{aligned}
\overline{\mathrm{C}}= & (\mathrm{CO})+\left(\mathrm{CO}_{2}\right)+\left(\mathrm{CH}_{4}\right) \\
\overline{\mathrm{O}}= & (\mathrm{CO})+2\left(\mathrm{CO}_{2}\right)+\left(\mathrm{H}_{2} \mathrm{O}\right)+2\left(\mathrm{O}_{2}\right) \\
\overline{\mathrm{H}}= & 2\left(\mathrm{H}_{2}\right)+2\left(\mathrm{H}_{2} \mathrm{O}\right)+4\left(\mathrm{CH}_{4}\right) \\
\overline{\mathrm{N}}= & 2\left[1-(\mathrm{CO})-\left(\mathrm{CO}_{2}\right)-\left(\mathrm{CH}_{4}\right)-\left(\mathrm{H}_{2}\right)-\left(\mathrm{H}_{2} \mathrm{O}\right)\right. \\
& \left.-\left(\mathrm{O}_{2}\right)\right]=2\left(\mathrm{~N}_{2}\right)
\end{aligned}
$$

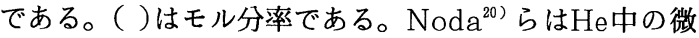
量不純物ガスによるステンレス鋼の酸化の理論的考察を 行っている。この場合む平衡図はコンピュータ支援の手 法を採用している。

\section{4. 合金の酸化}

合金ABの酸化を考える。Aは溶媒元素， B が溶質元

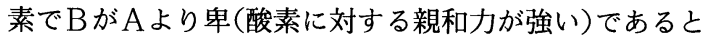
し, 雾囲気は酸素ポテンシャルを制御できる $\mathrm{H}_{2}-\mathrm{H}_{2} \mathrm{O}$ 混 合雾囲気とする。この混合雾囲気の酸素分圧は $\mathrm{H}_{2} \mathrm{O}$ が 解離した微量酸素であって，これからの記述では，この 量は主として $\mathrm{A} / \mathrm{AOO}$ 平衡酸素解離圧 $; \mathrm{Fe}$ の場合は $\mathrm{P}_{\mathrm{O}_{2}}=$ 4.29Pa以下とする。

\section{1 初期酸化（酸素吸着亡酸化物の生成）}

金属表面の酸素吸着と酸化物の生成について, 新居 ${ }^{21)}$ は雾囲気の酸素ポテンシャルの増加にともない(1)酸素分 子がほとんど弾性衝突をしている領域（状態 I ), (2)表 面の金属原子と酸素原子との間に相互作用が生じ, 酸素 が滞留するようになる領域（同 II），(3)表面の酸素が金 属格子に組み込まれるようになり，金属原子と二次元的 な規則的配列を形成するような領域。金属表面の原子は
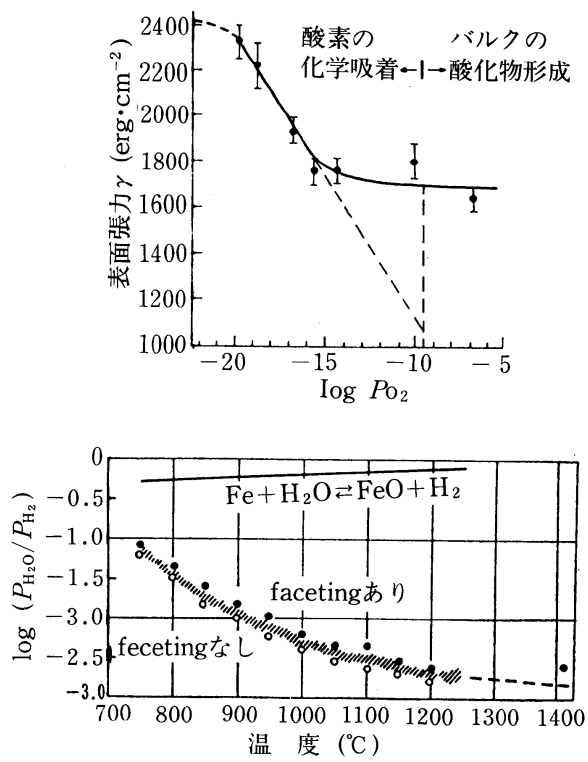

図 3-(1) $\mathrm{Fe}$ の表面張力におよぼす酸素圧の影響, 1683Kにおけ る $\delta-\mathrm{Fe}$ 表面の表面張力の変化,

-(2) Fe表面のfacetingの生成領域, 1323Kにおけるの印は 鉄の表面に屈曲点の現れる位置（文献 $21 ， 22 ， 23$ ）

本来内部原子よりも表面張力だけ高い化学ポテンシャル を有するので，このような状態の酸素ポテンシャルでも 二次元的酸化物を生成する。しかし雾用気の酸素ポテン シャルはまだ $\mathrm{Fe} / \mathrm{FeO}$ 平衡酸素圧よりあはるかに低い (同III), そして, (4)この $\mathrm{Fe} / \mathrm{FeO}$ 平衡酸素圧を越えた状 態で，表面は酸化物被覆で覆われその上に酸素が吸着し た状態になる領域（同IV）に分類した。Bénard ${ }^{22)}$ は facetingにおよぼす酸素吸着の実験から金属表面の状態 を(1)酸素と相互作用のない領域, (2)二次元的化学吸着を 形成する領域および(3)三次元的吸着層を形成する領域の 3 つの領域に分類した。そして, Hondros ${ }^{23)}$ が行った

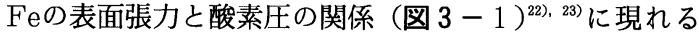
曲線の折れ部がfacetingの境界に一致することからその 折れ部が彼の領域(1)と（2）の境界としたが（図 3-2）, しかし， 新居 ${ }^{21)}$ はHondrosの折れ部がなお酸素吸着の 領域のまん中にあることから，ここをあって酸素と相互 作用のない表面とすることはできないとしている。状態 IIIにおいて金属内部に組み込まれた酸素が金属に溶解す ると，金属内部に拡散して固溶する。また，生成される 酸化物はエピタキシャルに核成して成長する。金属・合 金表面のガス吸着と吸着層の構造については電子回折 $(\mathrm{HEED})^{24)}$ ，低速電子回折 $(\mathrm{LEED})^{25)}$ などによる多く の研究結果があるので，ここでは省略する。ただ， Howes $^{26)}$ が行った28.4\%Cr-Feを1.34〜 $1.34 \times 10^{-2} \mathrm{~Pa}$ の酸素雾囲気中で1273〜1373K × 5〜18000s加熱したと きにみとめられる初期酸化物の核成・成長を透過型電子 
顕微鏡で観測した結果によれば，この酸化条件（温度・ 時間）では, 酸素圧が $1.43 \times 10^{-2} \mathrm{~Pa}$ 以下でcubic か hex.の $\mathrm{Cr}_{2} \mathrm{O}_{3}$ か $\alpha-\mathrm{Fe}_{2} \mathrm{O}_{3}$ の結晶の核, 1.34Pa以上で はcubicな $(\mathrm{Fe} \cdot \mathrm{Cr})_{3} \mathrm{O}_{4}$ か $\gamma-\mathrm{Fe}_{3} \mathrm{O}_{4}$ の皮膜であり, $\alpha$ $\mathrm{Fe}(\mathrm{Cr})$ とエピタキシャルの関係 $\left(\{111\}_{\text {ox }} \| .\{110\}_{\text {all }}\right.$,

$\langle 110\rangle_{\text {ox }}\left\|\langle 100\rangle_{\text {all }} ;\{111\}_{\text {cub. }}\right\|\{0001\}_{\text {hex. }},\langle 110\rangle_{\text {cub }}$. $\left.\|\langle 1120\rangle_{\text {hex. }}\right)$ にあった。このほか, 合金中のイオウ が初期酸化皮膜の生成に大きな影響をおよぼすとの報 告 ${ }^{27)}$ ある。また, 真空中あるいは低酸素ポテンシャル 雾囲気中で加熱した試料表面の偏析および酸素の吸着, 例えば, $\mathrm{S}, \mathrm{N}(\mathrm{Nb}), \mathrm{P}(\mathrm{Fe}, \mathrm{Ni}), \mathrm{N}(\mathrm{Cr}), \mathrm{C}$, な゙ の偏析および共偏析については新居, 吉原の論文 ${ }^{28,29)}$ と 解説 ${ }^{30}$ がある。

\section{2 遷移酸化一定常状態酸化への推移}

合金 $\mathrm{AB}$ (AよりもBの方が卑，前述）をBが選択酸 化する条件で酸化しても, 酸化の初期においては雾囲気 の酸素ポテンシャルいかんにかかわらず成分元素 $A, B$ はすべて酸化され合金表面にそれぞれの酸化物 $\mathrm{AO}$, $\mathrm{BO}_{\nu}$ の核を生成する (初期酸化の酸化物) $)^{27)}$, 31, 32)。酸化 物の核は時間の経過とともに成長し, 酸化層（以下，ス ケールと呼称）を形成するが，スケールが一旦合金表面 を覆うと酸化物の核の成長は酸化物中のイオンの拡散と 合金中の成分元素の拡散に依存する。あし，Bの含有量 が極めて少ないか, AO中のAイオンの拡散速度が大き いときは，優先的にAOが生成される（Bが溶媒元素の

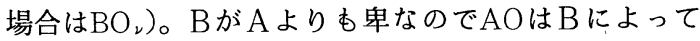
還元されるが (置換反応) $)^{33)}$, 合金/スケール界面の酸素 ポテンシャルはBO ${ }_{\nu}$ の解離酸素圧に近いか低くなってい るから, $\mathrm{BO}_{\nu}$ の成長は少なく $\mathrm{AO}$ が優先的に成長しその 厚さを増大していく。 $\mathrm{AO}, \mathrm{BO}_{\nu}$ いずれの場合も, $\mathrm{AO}$

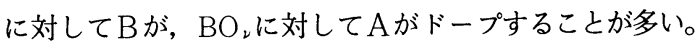
$\mathrm{B}$ 含有量がこの中間の場合は, $\mathrm{AO}$ と $\mathrm{BO}$ っを生成する

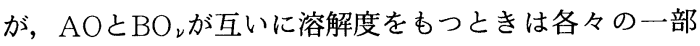
加全律の固溶体を形成する。

また，AOのBによる置換反応は， $\mathrm{AO}, \mathrm{BO}_{\nu}$ の標準 生成自由エネルギー（Ellingham Diagram：酸素 1 モルあたりの標準生成ギブズ自由エネルギー， $\Delta G^{\circ}{ }_{\mathrm{T}}-$

T) の間の差が大きいほど促進される。例えば,

$$
\begin{aligned}
& \nu / 2\langle\mathrm{AO}\rangle+\{\mathrm{B}\}=\left\langle\mathrm{BO}_{\nu}\right\rangle+\nu / 2\{\mathrm{~A}\} \\
& K_{\mathrm{P}}=\exp \left\{\left(\Delta G_{\mathrm{AO}}^{\circ}-\Delta G_{\mathrm{BO} \nu}^{\circ}\right) / R T\right\}
\end{aligned}
$$

であって, $\mathrm{Cr}-\mathrm{Ni}, \mathrm{Cr}-\mathrm{Fe}$ 系で考えられている置換反応 は,

$$
\begin{aligned}
& 3\langle\mathrm{NiO}\rangle+2\{\mathrm{Cr}\}=\left\langle\mathrm{Cr}_{2} \mathrm{O}_{3}\right\rangle+3\{\mathrm{Ni}\} \\
& 3\langle\mathrm{FeO}\rangle+2\{\mathrm{Cr}\}=\left\langle\mathrm{Cr}_{2} \mathrm{O}_{3}\right\rangle+3\{\mathrm{Fe}\}
\end{aligned}
$$

である。

図 4 は高 $(20 \sim 40) \mathrm{Cr}-\mathrm{Ni}$ 合金と低 ( 5 ) Cr-Ni合金の遷 移酸化の定常酸化への過程を示す ${ }^{34)}$ 。この全律固溶体合 金系で予想される酸化物は $\mathrm{NiO}(\mathrm{Cr} イ$ オをドープ),

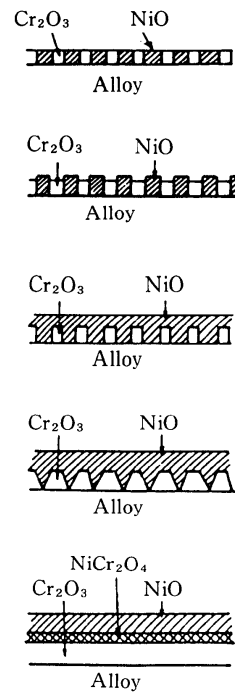

(a)
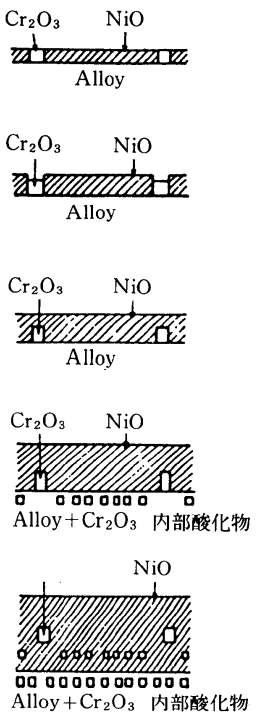

(b)
図 4 遷移酸化之定常酸化への移行を示す模式図, (a) 高 $\mathrm{Cr}-\mathrm{Ni}$ 合金 $(\mathrm{Ni}-20 \sim 40 \mathrm{Cr}$ ), (b) 低Cr-Ni合金 (Ni- $5 \mathrm{Cr}$ ); 低 $\mathrm{Cr}$ 合金, (文献 34)

$\mathrm{Cr}_{2} \mathrm{O}_{3}$ および $\mathrm{NiCr}_{2} \mathrm{O}_{4}$ である。はじめ, $\mathrm{NiO}_{2} \mathrm{Cr}_{2} \mathrm{O}_{3}$ が生成されるが，NiO中の陽イオンの拡散が速いため, $\mathrm{Cr}_{2} \mathrm{O}_{3}$ をのこして厚いスケールを形成する。 $\mathrm{Cr}_{2} \mathrm{O}_{3}$ はス ケール内で合金界面に沿って成長し, 高Cr-Ni合金では 単独の連続層を形成するにいたる（内部酸化の高濃度成 長)。これに対して，低Cr-Ni合金ではCr量が少ないの で内部酸化層を形成する (次節参照)。両合金ともに, この間に $\mathrm{NiO} と \mathrm{Cr}_{2} \mathrm{O}_{3}$ が固相反応を起こして $\mathrm{NiCr}_{2} \mathrm{O}_{4}$ を生成する。このようにスケールは雾囲気の酸素ポテン シャルに応じて熱力学的に安定な酸化物が層状になって 存在し, $\mathrm{BO} \nu, \mathrm{AO}$ および $(\mathrm{A} ・ \mathrm{~B})_{3} \mathrm{O}_{4}$ の多層構造の酸 化層を形成する。以上のことから，遷移酸化において重 要な因子は ${ }^{34)}$, 合金組成, 関連する酸化物の標準ギブズ 自由エネルギー，合金相互拡散係数，合金の酸素溶解度 之酸素の拡散係数，イオン・ドープ酸化物の格子欠陥, 成長速度, エピタキシ・トポタキシー効果打よび温度や 酸素ポテンシャルなどの酸化条件であることが分かる。

\section{3 内部酸化亡外部酸化}

合金に固溶した酸素は合金内部に拡散し，合金内部で $\mathrm{B}$ と会合して $\mathrm{BO}_{\nu}$ を生成する。合金組成 $\mathrm{B}$ の濃度が高い と内向拡散の酸素を合金表面近くで捉えるので連続した (外部酸化層) を形成する。しかし，内向拡散する酸素 の量が多く(合金中の酸素拡散係数, $D_{0}$, が大きい) て, バルク濃度, $\mathrm{N}_{\mathrm{B}}^{(0)}$, が少なく, かつ合金の相互拡散釈数,

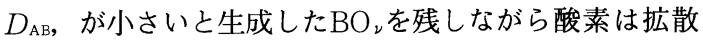
しその先端で $\mathrm{B}$ と会合するので合金内部で酸化物を形成 するようになる。これを前述の合金表面に生成される連 
続酸化層を形成する外部酸化に対して内部酸化という。 内部酸化による生成酸化物はおおむね板状か粒状で多く の場合マイクロヴォイド（microvoids）を伴うことが ある。三吉 ${ }^{35)}$ によればその形態は 5 種類である。

Wagner ${ }^{36)}$ は, 外部酸化層を伴わない内部酸化層の成 長速度 (動力学) について理論的解析を行った。内部酸 化層の厚さ, $\xi$, は時間, $t$, の放物線関数であって次 のように与えられる。

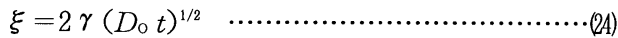

$$
\begin{aligned}
& d \xi / d t=\gamma\left(D_{\circ} / d t\right)^{1 / 2} \quad \ldots \ldots \ldots \ldots \ldots \ldots \ldots \ldots \ldots \ldots(25)
\end{aligned}
$$

ここに，Doは合金におけるの酸素の拡散係数， $\gamma$ は (29)式から求められる無次元パラメーターである。

酸素とBの拡散をFickの第二法則にあてはめ, $d N_{\mathrm{o}}$ $/ d t=D_{0}\left(d^{2} N_{\mathrm{o}} / d^{2} x\right)$ と $d N_{\mathrm{B}} / d t=D_{\mathrm{AB}}\left(d^{2} D_{\mathrm{AB}} / d^{2} x\right)$ を境 界条件（酸素に対しては, $x=0, t>0$ のとき $N_{0}=$ $N_{0}^{(\mathrm{S})}, x \geq \xi, t>0$ のとき $N_{0}=0, \mathrm{~B}$ については, $x>$ $0, t=0$ のとき $N_{\mathrm{B}}=N_{\mathrm{B}}^{(0)} ; x \leq \xi, t>0$ のとき $N_{\mathrm{B}}=$ $0)$ について解く之, 次の解が得られる。

$$
\begin{aligned}
& N_{\mathrm{O}}=N_{\mathrm{O}}^{(\mathrm{S})}\left[1-\frac{\operatorname{erf}\left\{x / 2\left(D_{\mathrm{O}} t\right)^{1 / 2}\right\}}{\operatorname{erf} \gamma}\right] \\
& N_{\mathrm{B}}=N_{\mathrm{B}}^{(\mathrm{O})}\left[1-\frac{\operatorname{erfc}\left\{x / 2\left(D_{\mathrm{B}} t\right)^{1 / 2}\right\}}{\operatorname{erfc} \gamma \phi^{1 / 2}}\right]
\end{aligned}
$$

$\phi=D_{\circ} / D_{\mathrm{AB}}, \quad \operatorname{erf}$ は䛊差関数, erfcは余誤差関数であ る。

内部酸化層の先端で外側から拡散してくる酸素と内側 から拡散してくるBとは量的に等しくなければならない から,

$$
\lim _{\epsilon \rightarrow 0}\left[-D_{\mathrm{O}}\left(d N_{\mathrm{O}} / d x\right)_{\mathrm{x}=\xi-\theta}=\nu D_{\mathrm{B}}\left(d N_{\mathrm{B}} / d x\right)_{\mathrm{x}=\xi+\theta}\right] \cdot(28)
$$

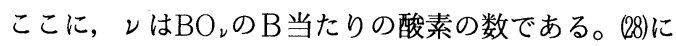
(26)と(27)を入れて整理すると,

$$
\frac{N_{\mathrm{O}}^{(\mathrm{S})}}{\nu N_{\mathrm{B}}^{(0)}}=\frac{\exp \left(\gamma^{2}\right) \operatorname{erf} \gamma}{\phi^{1 / 2} \exp \left(\gamma^{2} \phi\right) \operatorname{erfc}\left(\gamma \phi^{1 / 2}\right)} \cdots \cdots \cdots \cdots \cdots(29)
$$

が得られる。

$\gamma$ は図式解法か数值計算で解く。 $\gamma$ は(30)版よび(33)式か ら明らかなように時間に無関係であって,このことは実 験的に確かめられている。 $\gamma$ が求められれば, 内部酸化 層の厚さおよび内部酸化層の先端の移動速度 (内部酸化

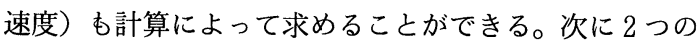
事例において得られた值を示す。

$[\mathrm{I}] \gamma \ll 1$ と $\gamma \phi^{1 / 2} \gg 1$, すなわち $D_{\mathrm{B}} / D_{0} \ll N_{0}^{(\mathrm{S})} / N_{\mathrm{B}}^{(\mathrm{o})}$ $\ll 1$ の場合は，(29), (24)と(25)式は次のようになる。

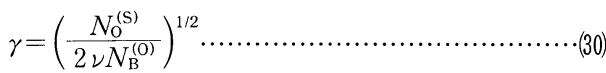

$$
\begin{aligned}
& \xi=\left(\frac{2 N_{\mathrm{O}}^{(\mathrm{S})} D_{\mathrm{O}} t}{\nu N_{\mathrm{B}}^{(\mathrm{O})}}\right)^{1 / 2} \\
& \frac{d \xi}{d t}=\left(\frac{N_{\mathrm{O}}^{(\mathrm{S})} D_{\mathrm{O}}}{2 \nu N_{\mathrm{B}}^{(0)} t}\right)^{1 / 2}
\end{aligned}
$$

また,

$[$ II] $] \gamma \ll 1$ と $\gamma \phi^{1 / 2} \ll 1$, すなわち $N_{\mathrm{O}}^{(\mathrm{S})} / N_{B}^{(0)} \ll D_{\mathrm{B}} / D_{\mathrm{O}}$ $\ll 1$ の場合は,

$$
\begin{aligned}
& \gamma=(\pi \phi)^{1 / 2} N_{\mathrm{O}}^{(\mathrm{S})} / 2 \nu N_{\mathrm{B}}^{(\mathrm{O})} \ldots \cdots \cdots \\
& \xi=(\pi \phi)^{1 / 2} N_{\mathrm{O}}^{(\mathrm{S})}\left(D_{\mathrm{O}} t\right)^{1 / 2} / \nu N_{\mathrm{B}}^{(\mathrm{O})}
\end{aligned}
$$

この二つの事例で内部酸化層の濃度分布を求めると図 5 と 6 のようになる。すなわち，［Ｉ］の場合は内部酸化 の過程ではBの拡散は少なく内部酸化層にはBの富化は ない。これに対して $[\Pi]$ は Bの拡散が大きく，したがっ て内部酸化層内のBの富化が見られ内部酸化層と合金界 面にはBの欠乏層がある。

内部酸化層と外部酸化層が同時に起こる場合は，(29） 式の関係は $\mathrm{Maak}^{37)}$ によって次のように与えられている。

$$
\frac{\mathrm{N}_{O}^{(\mathrm{S})}}{\nu \mathrm{N}_{\mathrm{B}}^{(0)}}=\frac{\exp \left(\gamma^{2}\right)\left[\operatorname{erf}(\gamma)-\operatorname{erf}\left(k_{\mathrm{p}} / 2 \mathrm{D}_{\mathrm{O}}\right)^{1 / 2}\right]}{\phi^{1 / 2} \exp \left(\gamma^{2} \phi\right) \operatorname{erfc}\left(\gamma \phi^{1 / 2}\right)}
$$

内部酸化層に流入する B の量はFickの第一法則によ れば $D_{\mathrm{AB}} \frac{\partial N_{\mathrm{B}}}{\partial x}$ のオーダーであるから $D_{\mathrm{AB}}$ および $N_{\mathrm{B}}^{\mathrm{x}}$ が大 きければ外部酸化層に移行することが推測され，スケー ルの組織はバルクのB濃度に依存することが知られる。 Atkinson $^{38)}$ はこれらの関係を図7のように総括した。 図に示すスケールの形態を見るとBだけが酸化して $\mathrm{BO}_{\nu}$ を生成する場合, $\mathrm{A}$ も $\mathrm{B}$ 酸化し $\mathrm{AO}$ と $\mathrm{BO}_{\nu}$ を生成 するが，その各々が全く固溶しないか，あるいは固溶す るが完全であるか不完全であるかによってスケールの組

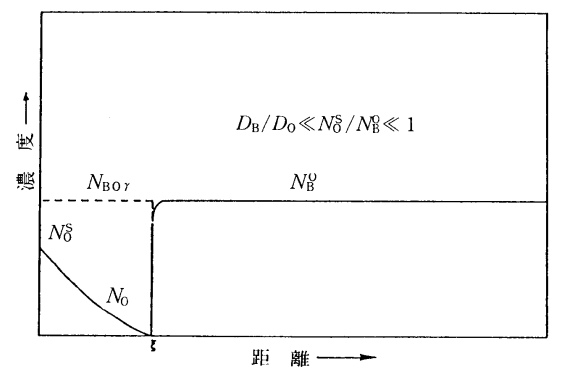

図 $5 \gamma \ll 1, \gamma \phi^{1 / 2} \gg 1$ において生成された外部酸化を伴わ ない内部酸化層の組成分布（文献 $33 ， 40 ， 54$ )

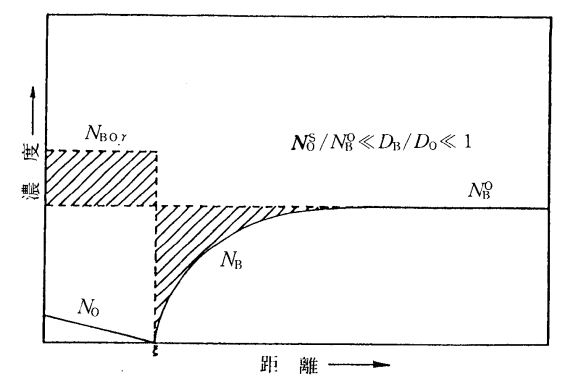

図 $6 \gamma \ll 1, \gamma \phi^{1 / 2} \ll 1$ において生成された外部酸化を伴わ ない内部酸化層の組成分布（文献 $33 ， 40,54$ ) 
織は著しくことなる。この相関図についてはBastow $ら^{399}$ が二元系スケール形態図として詳しく総括している ので参照されたい。ここではAtkinson ${ }^{38}$ によるBのみ, あるいは $\mathrm{A}$ あ $\mathrm{B}$ あ酸化したときの形態図を示した。図7 の上段が $\mathrm{B}$ のかが酸化して $\mathrm{BO}_{\nu}$ を，下段が $\mathrm{AO}$ と $\mathrm{BO}_{\text {レ }}$ を 生成する場合である。大別すると 3 つの組成領域（外部 酸化層をいれると 4 つ）に分かれることが知られる。そ して，その境界は合金組成に依存し，それぞれの境界濃 度は $N_{\mathrm{B}}^{(0)}(\mathrm{I}$, II $), N_{\mathrm{B}}^{(0)}(\mathrm{OX})$, および $N_{\mathrm{B}}^{(0)}($ II, III $)$ で 与えられ，その值は次のようである。

$$
\begin{aligned}
& N_{\mathrm{B}}^{(\mathrm{O})}(\mathrm{I}, \mathrm{II})=0.3 \frac{V_{\mathrm{AB}}}{V_{\mathrm{BO} \nu}} F\left(\gamma \phi^{1 / 2}\right) \cdots \cdots \cdots \cdots \cdots \cdots \cdots \cdots \cdots \cdots \cdots \cdots(36) \\
& N_{\mathrm{B}}^{(\mathrm{O})}(\mathrm{ox})=F\left\{\frac{V_{\mathrm{AB}}}{V_{\mathrm{BO} \nu}}\left(\frac{K_{\mathrm{P}}}{4 D_{\mathrm{AB}}}\right)^{1 / 2}\right\} \\
& N_{\mathrm{B}}^{(\mathrm{O})}(\mathrm{II}, \mathrm{III})=\frac{\nu F(u)+\pi^{1 / 2} u \phi^{1 / 2}}{\nu+\pi^{1 / 2} u \phi^{1 / 2}}
\end{aligned}
$$

$V_{\mathrm{AB}}$ は合金 $\mathrm{AB}$ のル体積, $V_{\mathrm{BO}_{\nu}}$ は酸化物 $\mathrm{BO}_{\nu}$ のモル 体積, $k p$ は外部酸化層の放物線則酸化速度定数 $\left(X^{2}=\right.$ $k p \cdot t)$ である。 $u$ は $\left(k_{1} / 4 D_{\mathrm{AB}}\right)^{1 / 2}, k_{\mathrm{l}}$ は $k_{\mathrm{P}}\left(V_{\mathrm{AB}} / V_{\mathrm{BO}_{\nu}}\right)^{2}$, $F[u]$ は次のとおりである。

$$
F(u)=\pi^{1 / 2} u \exp \left(u^{2}\right) \operatorname{erfc}(u)
$$

図において，第四の領域は，外部酸化層だけの領域で ある。第二, 第三は, 外部酸化層之内部酸化層とが共存 する領域である。第一の領域は, 外部酸化層が全くない 領域で内部酸化層だけの領域である。

内部酸化層が事例（II）で生成される場合は，内部酸 化層内にBが富化する ${ }^{40)}$ 。このときの内部酸化層内の富
化率を $\alpha\left(=f / N_{\mathrm{B}}^{(0)}\right)$ とすると，

$$
\alpha=\left\{\pi^{1 / 2} \gamma \phi^{1 / 2} \exp \left(\gamma^{2} \phi\right) \operatorname{erfc}\left(\gamma \phi^{1 / 2}\right)\right\}^{-1}
$$

$f$ は内部酸化層の $\mathrm{BO}_{\nu}$ としてのBの原子分率である。

外部酸化層を伴う場合は, すなわち, 第二, 第三領域 のスケールの成長では, 生成される内部酸化層の厚さは, 外部酸化層の成長が放物線則に従う場合と, 直線則に従 うときとでことなる ${ }^{40,41)}$ 。

外部酸化層が放物線則 $\left(k_{\mathrm{P}}=X^{2} / 2 \mathrm{t}\right)$ に従って成長する ときは, 通常の $\gamma \ll 1, X \ll \xi の$ 場合は,

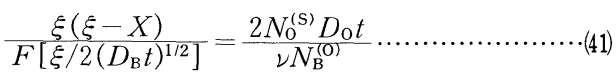

があたえられる。

ここでは, $N_{0}^{(\mathrm{S})}$ は合金/酸化物層の界面における酸素 のモル分率とする。 $\xi$ は時間 $t$ における内部酸化層先端 の位置 (バルク合金表面が基準)， $X$ は同様に時間 $t$ にお ける合金/スケール界面の位置 (同上), $F[u]$ は補助関 数で (39)式のようである。

次に, 外部酸化層が直線則に従って成長するときの内 部酸化層の厚さは,

$$
\left\{(\zeta-X)^{*}=\left(D_{\mathrm{O}} / b\right) \ln \left\{\left(N_{\mathrm{O}}^{(\mathrm{S})}+\nu N_{\mathrm{B}}^{(\mathrm{O})}\right) / \nu N_{\mathrm{B}}^{(\mathrm{O})}\right\} \cdots \cdots \cdots(42)\right.
$$

のように与えられる。 $(\xi-X)^{*}$ は酸化が進行して内部 酸化が定常状態になったときの $(\xi-X)$ の厚さでその 後の酸化においては一定となる。

外部酸化層の成長速度はそれぞれ $d X / d t=k p / X お よ ~$ び $d X / d t=b$ である。

4. 4 粒界酸化

合金が内部酸化を起こすと, 合金元素の種類（例えば,

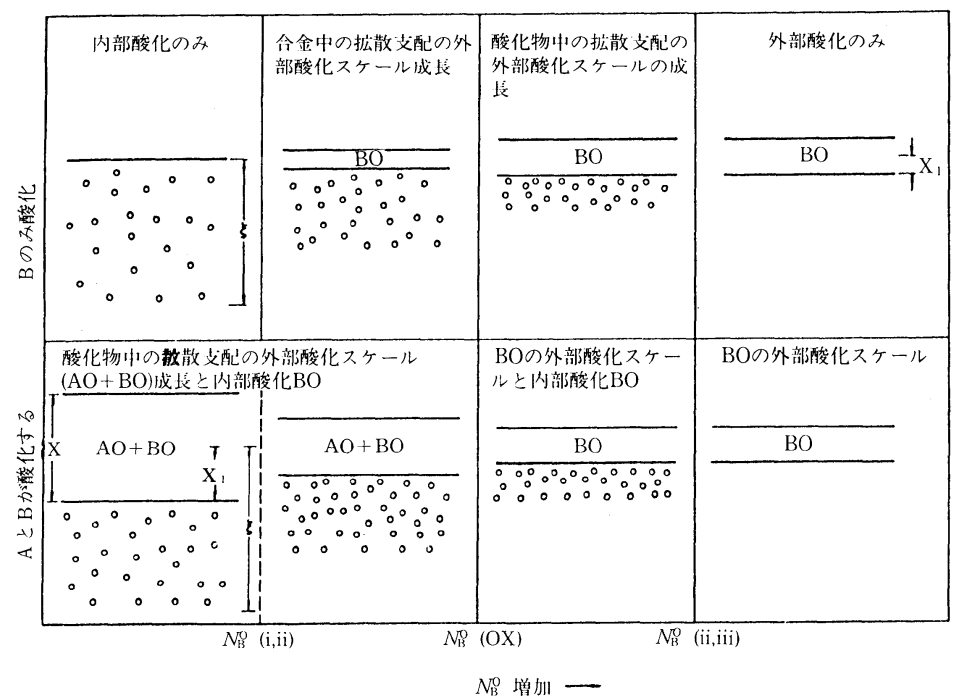

図 7 卑金属元素Bを含む合金ABの定常酸化スケールの顕微鏡組織におよぼす組成の影響, (a)Bの選択酸化, (b) AもBも酸化され る条件 (文献38) 


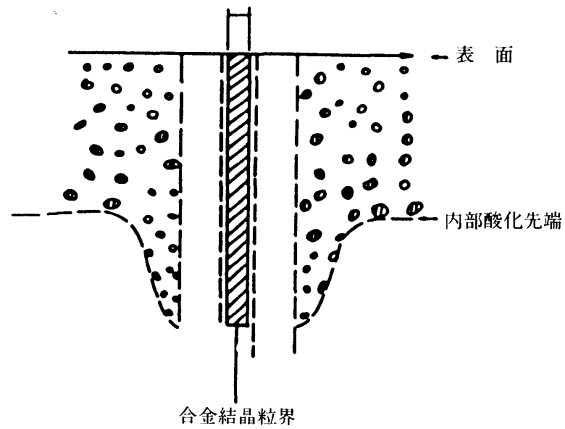

図 8 粒界酸化の模式図（文献 $34 ）$

$\mathrm{Al}$ な゙）と酸化条件（低温酸化）によっては内部酸化 が促進されると同時に合金の結晶粒界に沿って酸化が優 先的に進行する $(\text { 粒界酸化 })^{42}$ 。これは内部酸化物と合 金マトリックスとの間に不整合（incoherent）な界面 が形成され酸素の拡散が助長されるためと考えられてい

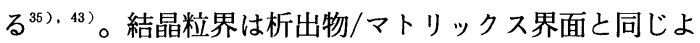
うに不整合であって, 酸化物の核成サイトあ多く過飽和 度が低くてあ核成するため優先的に酸化物を生成し合金 内部に深く侵入する ${ }^{44)}$ 。また，内部酸化首では酸化物の モル容積 $\left.\left(V_{\mathrm{BO}_{\nu}}, \quad \alpha-\mathrm{Al}_{2} \mathrm{O}_{3}: 25.6 \mathrm{~cm}^{3}\right)^{45}\right)$ が合金バルク の原子容積 $\left(V_{\mathrm{AB}}, \mathrm{Ni}-\mathrm{Al} \text { 合金 : } 6.67 \mathrm{~cm}^{3}\right)^{45}$ 上りも大き いので内部酸化層先端の結晶粒界には応力誘起マイクロ ヴォイドが発生し酸化物の核生成を促進する。同じよう な現象が粒界酸化層であ発生する。粒界酸化首に沿って 合金元素の欠乏層が生成されると，酸素はこの久乏層を 通って合金素地（バルク濃度の位置）に到達し，そこで 内部酸化物粒子を析出する。図 8 は代表的な粒界酸化層 の模式図 ${ }^{34)}$ である。

Whittle ${ }^{43)}$ は内部酸化が $D_{\mathrm{B}} / D_{0} \ll N_{0}^{(\mathrm{s})} / N_{\mathrm{B}}^{(0)} \ll 1$ (図 5 参照）の条件で進行したとし, 内部酸化層の析出物の形 態が板状であるとして酸素の格子拡散に対する内部酸化 層中の有効拡散係数の比, $D_{0}$, eff $/ D_{0}, 1$ を求めた。板状析 出物の深さを $\xi$, 幅を $d$, 長さを $\omega$ とし, 内部酸化層の $\mathrm{BO}_{\nu}$ のモル分率を $N_{\mathrm{BO}_{\nu}}$ ，酸化物と合金のモル容積をそ れぞれ $V_{\mathrm{BO}_{\nu}}$ および $V_{\mathrm{AB}}$, 酸化物/合金界面における酸素 の拡散係数之合金中の格子拡散係数を $D_{0},{ }_{\mathrm{i}}$ および $D_{0}, 1$ とすると次のと抢りである。(図 9 参照)。

$$
\frac{D_{\mathrm{O}}, \text { eff }}{D_{\mathrm{O}, 1}}=1+\left[\frac{D_{\mathrm{O}, \mathrm{i}} \xi_{\mathrm{i}}}{D_{\mathrm{O}, \mathrm{i}}} \frac{2}{d}-1\right] \frac{V_{\mathrm{OX}}}{V_{\mathrm{AB}}} N_{\mathrm{BO} \nu} \cdots \cdots \cdot(43)
$$

この式から比, $D_{0}$, eff $/ D_{\mathrm{o}}, 1$ は $N_{\mathrm{BO}_{\nu}}$ に比例し, したがっ て $N^{\circ}{ }_{B}$ に比例することが知られる。

内部酸化および粒界酸化の促進は酸化物が合金相およ び結晶粒界で析出するときに発生する高い内部応力によ るマイクロヴォイドなどの格子欠陥が原因で酸素の拡散 が助長されて起こるあのである。したがって，モル容積

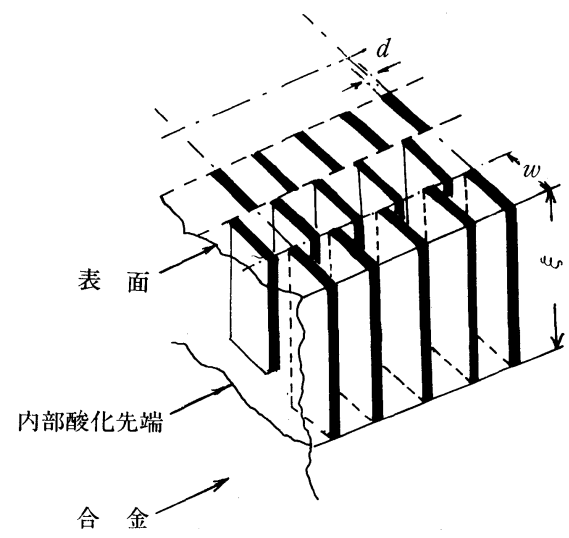

図 9 粒界酸化モデルの模式図（文献 43）

の大きい析出物が発生しても高温度のように塑性変形を 起こし応力を吸収することができればその要因は減少す る。この応力除去は内部酸化物のサイズが大きく，しか 屯析出物間の間隔が広いときに起こりやすい。Ni-Al合 金です $1,100^{\circ} \mathrm{C}$ 以上の温度では粒界酸化は起こらない22)。 また，モル容積の小さい酸化物の析出であれば粒界酸化 の可能性は小さい。 Ni-Cr 合金がよい(例年である。

\section{5 酸化スケールのイオン分布}

合金 $\mathrm{AB}$ 外部酸化層は雾囲気の酸素ポテンシャルに 応じてスケール表面から順に酸素解離圧の大きい酸化物 から低い酸化物への多首構造を形成する。しかす，スケー ル/合金界面に近く杽金属の酸化物が優先的に生成（選 択酸化）され，スケール中の陽イオン $\mathrm{A}$ と B の拡散速度 がことなるときはスケール中の陽イオンの濃度比，A／ Bがスケール/合金界面からスケール最表面に向かって 変化する。

Wagner ${ }^{46)}$ はこのような 2 元系合金のスケール (monoxides)の陽イオン分布に関する理論を提出して いる。その後Coates\&Dalvi ${ }^{47)}$ およびWhittle ${ }^{48}$ らによっ て拡張された。図10はBastow ${ }^{49)}$ がこれまでの理論式 を用いて外部酸化層内の陽イオン分布, 同内の酸化物の モル数, 溶質元素Bのモル分率, 析出酸化物中のBのモ ル分率，析出物と平衡する合金素地における酸素のモル 分率などを総括した図である。（記号の意味は原著によ る)。

㫣金属元素Bの濃度が高い合金では，スケール中の陽 イオンの拡散係数か酸化物組成之酸素活量に大きく依存 するので図10に示した $j_{\mathrm{i}}$ の二つの微分方程式を解くには 数值計算を必要とする。これまでに行われた研究でいろ いろと試みられた方法をBastow ${ }^{49)}$ が総括しているの で, 詳細を知りたい方は原著を参照されたい。通常, ス ケール/合金界面からスケール/霑囲気界面に向かって $\mathrm{BO}_{\nu}$ 当量濃度が増大するが，合金元素の種類によっては $\mathrm{B}$ 濃度および雾囲気の酸素ポテンシャルによって $\mathrm{D}_{\mathrm{A}} /$ $\mathrm{D}_{\mathrm{B}}$ が変化するのでBO 等量濃度は極大を示す ( $\mathrm{Co}-\mathrm{Fe}$ 


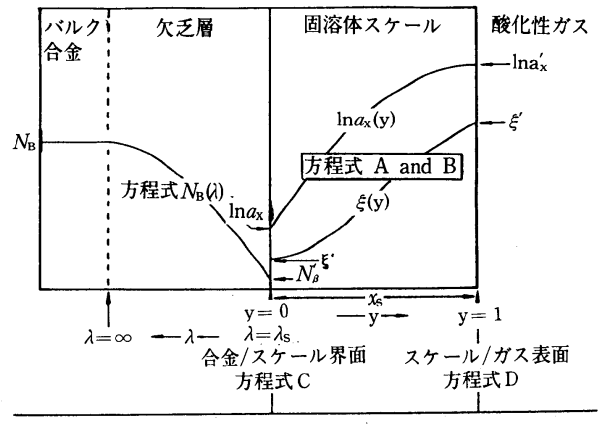

陽イオン, 酸化物およひ酸素のそれそれれの浴量によって表したスケール中の 陽イオンの拡散量, $j_{\mathrm{B}}$,

$j_{\mathrm{B}}=-\frac{D_{\mathrm{B}} \xi}{X_{\mathrm{s}} V_{\mathrm{eq}}} \frac{\partial \ln a_{\mathrm{B}}}{\partial y}$ または $j_{\mathrm{B}}=-\frac{D_{\mathrm{B}} \xi}{X_{\mathrm{s}} V_{\mathrm{eq}}}\left[\frac{\partial \ln a_{\mathrm{B}(\mathrm{x})}}{\partial \xi} \frac{d \xi}{d y}-\frac{Z_{\mathrm{B}}}{Z_{\mathrm{x}}} \frac{\partial \ln a_{\mathrm{x}}}{d y}\right]$

A フィックス第一法則によってもとめた放物線則酸化速度定数,

$k=-D_{\mathrm{A}}(1-\xi)\left[\frac{\partial \ln a_{\mathrm{A}(x)}}{\partial \xi} \frac{d \xi}{d y}-\frac{Z_{\mathrm{A}}}{Z_{\mathrm{X}}} \frac{d \ln a_{\mathrm{X}}}{d y}\right]-D_{\mathrm{B}} \xi\left[\frac{\partial \ln a_{\mathrm{B}(\mathrm{x})}}{\partial \xi} \frac{d \xi}{d y}-\frac{Z_{\mathrm{B}}}{Z_{\mathrm{x}}} \frac{d \ln a_{\mathrm{X}}}{d y}\right]$

B フィック第二法勋でもとめたスケール中の陽イオン分布

$-y k \frac{d \xi}{d y}=\frac{d}{d y}\left[D_{\mathrm{B}} \xi\left[\frac{\partial \ln a_{\mathrm{B}(\mathrm{x})}}{\partial \xi} \frac{d \xi}{d y}-\frac{z_{\mathrm{B}}}{z_{\mathrm{x}}} \frac{d \ln a_{\mathrm{x}}}{d y}\right]\right]$

C 合金とスケール面が平衝状態にあるとしてもとめた $\xi^{\prime}\left(=f\left(N_{\mathrm{B}}^{\prime}, a_{\mathrm{x}}^{\prime}, \Delta G_{\mathrm{B}(\mathrm{x})}^{\circ}\right)\right)$ の值と 物質収支,

$z_{\mathrm{B}} N_{\mathrm{B}}^{\prime}\left[\frac{1-\xi_{\mathrm{av}}}{z_{\mathrm{A}}}+\frac{\xi_{\mathrm{av}}}{z_{\mathrm{B}}}\right]+\sqrt{\frac{2}{k}} \frac{z_{\mathrm{B}} D_{\mathrm{all}} V_{\mathrm{eP}}}{V_{\mathrm{all}}}\left[\frac{d N_{\mathrm{B}}}{d \lambda}\right]=-\left[\frac{D_{\mathrm{B}} \xi}{k}\left[\frac{\partial \ln a_{\mathrm{B}(\mathrm{X})}}{\partial \xi} \frac{d \xi}{d y}-\frac{z_{\mathrm{B}}}{z_{\mathrm{X}}} \frac{d \ln a_{\mathrm{X}}}{d y}\right]\right]=\xi_{\mathrm{all}}$

D 外部表面に拡散してくる陽イオン Bによるスケールの成長、

$\xi^{\prime \prime}=-\left[\frac{D_{\mathrm{B}} \xi}{k}\left[\frac{\partial \ln a_{\mathrm{B}(x)}}{\partial \xi} \frac{d \xi}{d y}-\frac{z_{\mathrm{B}}}{z_{\mathrm{X}}} \frac{d \ln a_{\mathrm{X}}}{d y}\right]\right]_{y=1}$

$\mathrm{E}$ 合金の欠乏層における浱度变化

$N_{\mathrm{B}}^{\prime}=N_{\mathrm{B}}^{\prime}+\left(N_{\mathrm{B}}^{\prime}-N_{\mathrm{B}}^{\prime}\right) \frac{\operatorname{efr}\left(\lambda / 2 \sqrt{D_{\text {all }}}\right)-\operatorname{erf} \sqrt{\alpha / 2 D_{\text {all }}}}{\operatorname{erfc} \sqrt{\alpha / 2 D_{\mathrm{all}}}}$

図10 二元系合金の表面に生成された固溶体スケールの金属お よび酸素濃度の分布と酸化過程に関する理論式 (文献 49)

合金, 図11) ${ }^{50)}$ ことがある。図12はSUS 430の光輝焼 なまし材 $\left(\mathrm{H}_{2}-\mathrm{H}_{2} \mathrm{O}\right.$, d.p. $=221 \mathrm{~K}, 1033 \mathrm{~K} \times 0$ と600sec $)$ の酸化皮膜 $(759 \mathrm{~nm})$ の濃度分布をSIMSによって測定 した結果 ${ }^{51)}$ である。設定した霧囲気の $P_{\mathrm{H}_{2}}$ とd.p. とから $18 \% \mathrm{Cr}-\mathrm{Fe}$ 合金の酸化皮膜は $\mathrm{Cr}_{2} \mathrm{O}_{3}$ であるが，(18)式によ る $\mathrm{FeCr}_{2} \mathrm{O}_{4}$ 生成反応の $\mathrm{Po}_{2}\left(\mathrm{Fe}-\mathrm{Cr} / \mathrm{FeCr}_{2} \mathrm{O}_{4}\right)$ が(17)式に よる $\mathrm{Cr}_{2} \mathrm{O}_{3}$ 生成反応のそれ $\left(\mathrm{Fe}-\mathrm{Cr} / \mathrm{Cr}_{2} \mathrm{O}_{3}\right)$ に近いので 雾囲気のd.p.の僅かな変化によっては $\mathrm{FeCr}_{2} \mathrm{O}_{4}$ を生成 することがある。この場合においても, 初期酸化と遷移 酸化の節で記述したようにスケール最表面に $\mathrm{FeCr}_{2} \mathrm{O}_{4}$ を生成しスケール/合金界面に近く $\mathrm{Cr}_{2} \mathrm{O}_{3}$ を生成するこ とがX-線回折の結果確かめられている ${ }^{52)}$ 。SUS 430の 光輝焼なまし材 $\left(1133 \mathrm{~K} \times 100 \mathrm{sec}, P_{\mathrm{H}_{2}} 0.3-\mathrm{d} . \mathrm{p} .233 \mathrm{~K}\right.$, $\left.P_{\mathrm{O}_{2}}=4.78 \times 10^{-19} \mathrm{~atm}\right)$ の-線回折では熱力学的には $\mathrm{Cr}_{2} \mathrm{O}_{3}$ 安定生成領域であるが $\mathrm{MnAl}_{2} \mathrm{O}_{4}$ が確認されてい る ${ }^{51)}$ 。SUS 430のようにSi, Mnなど不純物元素を含む 場合はこれらの元素の影響を大きく受けることが知られ た。図13に安原ら ${ }^{53)}$ のSUS 430光輝焼なまし材の酸化 皮膜の相組成および結晶構造におよぼす酸素ポテンシャ ルと昇温過程の影響を示す。図中の丸の中の黒ぬり, 斜 線および白ぬきはそれぞれ $\mathrm{Cr}_{2} \mathrm{O}_{3}, \mathrm{Fe}_{2} \mathrm{O}_{3}$ および $\mathrm{FeCr}_{2} \mathrm{O}_{4}$ を示しその面積の多寡で量の大小を示した。雾囲気は主 として(1) $\mathrm{N}_{2}-5 \% \mathrm{H}_{2}$ で, なお比較のために(2) $\mathrm{N}_{2-1} \%$
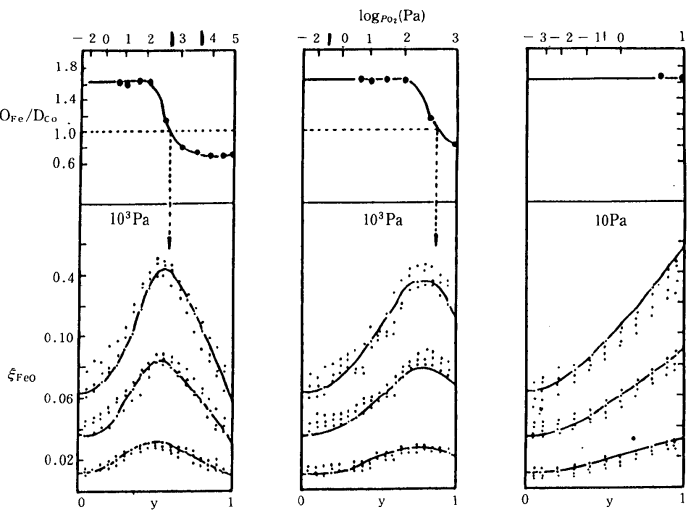

図11一酸化物スケールの陽イオン分布におよぼす酸素分圧の 影響， $2.2 ， 5.8$ おび 10.1 原子 $\% \mathrm{Fe}$ を含むCo合金を $1473 \mathrm{~K}$ に加熱, 低 $P_{\mathrm{O}_{2}}$ では $D_{\mathrm{Fe}} / D_{\mathrm{Co}}>1$, 高 $P_{\mathrm{O}_{2}}$ では $D_{\mathrm{F}_{0}} / D_{\mathrm{Co}}<1$ に変化した結果を示す。（文献 49）

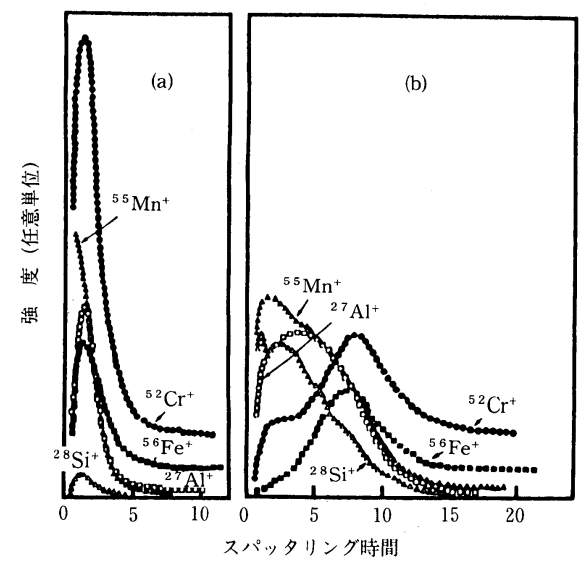

図12 SUS 430光輝焼なまし材の表面酸化皮膜の金属濃度分布, BA条件 : Ar $-30 \% \mathrm{H}_{2}$, d.p. $223 \mathrm{~K}, 1033 \mathrm{~K} \times 0$ (a)および $600 \mathrm{sec}(\mathrm{b})$ (文献 51)

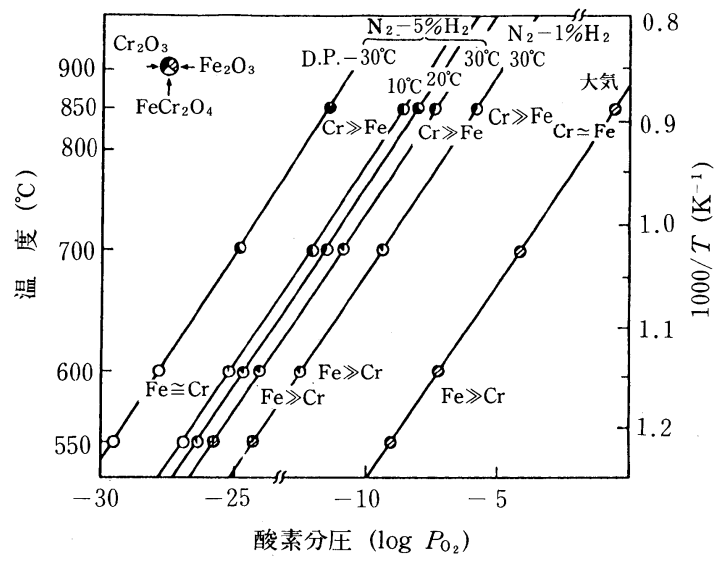

図13 SUS 430光輝焼なまし材の表面酸化皮膜の相組成之結晶 構造におよぼす酸素分圧の影響（文献 53） 
$\mathrm{H}_{2}$ ， d.p.303Kの混合気体および(3)大気を選んでいる。 (3)では823〜1123Kにおいて酸化皮膜はすべて $\mathrm{Fe}_{2} \mathrm{O}_{3}$ で あるのに対して(2)では823Kにおいて $\mathrm{Fe}_{2} \mathrm{O}_{3}$ であるが, $873 \mathrm{~K}$ 以上では $\mathrm{Cr}_{2} \mathrm{O}_{3}$ および $\mathrm{FeCr}_{2} \mathrm{O}_{4}$ の混合組織となる。 しかし，温度の上昇とともに $\mathrm{Cr}_{2} \mathrm{O}_{3}$ の量か増大している。 これに対して，(1)ではd.p.が303Kのとき(2)と同じとな るあののd.p.が下がるにつれて $\mathrm{Cr}_{2} \mathrm{O}_{3}$ の量が増えた。 d.p.が243Kにおいては1123Kの温度においてほとんど $\mathrm{Cr}_{2} \mathrm{O}_{3}$ であることが知られる。しかし，皮膜の構造は層 構造をとらず，モザイク状であるとしている。これは山 崎ら ${ }^{51)}$ の結果とことなる。

\section{5. 結言}

制御雾囲気における合金の酸化について記述した。制 御雾囲気における金属・合金の加熱はBAのみならず表 面改質への応用面が極めて多い。本稿は実用的視点から 制御雾囲気における合金の酸化を展望し使用目的に応じ た合金組成および雾囲気組成を選定するために必要な理 論背景を総括したつありである。

金属・合金の酸化の理論については多くの研究者が優 れた業績を残しているが，実用材料に適用するにはまだ 多くのデータが必要である。遷移酸化, 内部酸化, 外部 酸化および相互の関係, 多首外部酸化層, スケール/合 金面の組成・構造およびスケールの密着性を理論的に推 定するにはまだ充分ではない。不均一系反応の熱力学, 拡散などの動力学に関するデータの収集が必要である。 これまで得られている知見からでも与えられた合金を制 御雾囲気中で熱処理して所望の特性を発揮させることは ある程度可能であるが，なお得られたスケールとその使 用特性之の関係, 例えば耐食性などとの関係（キャラク タリゼーション）を把握することが大切であり, 今後の 研究が期待される。

\section{(1989-3-6 受理)}

\section{文献}

1) J. F. F. Rheed \& R. V. Wheeller ; J. Chem. Soc., 101, 846 (1912)

2) J. K. Clement, L. H. Adams \& C. N. Haskins ; Bureau of Mines, 7 (1911)

3 ) C. Benedicks u. H. Lofquit ; Z. V. D. I., 71, 1576 (1927)

4) H. Schenck ; Physikalischechem. u. Eisenhüttenprozesse, Bd. 1 u. 2, Berlin (1934)

5 ) 内田荘祐 ; 日本金属学会誌, 16, (3), 15 (1951)

6 ) 内田荘祐 ; 日本金属学会誌, 16, (8), 468（1952）

7 ) L. S. Darken \& R. W. Gurry ; Phys. Chem. of Metals, (McGraw-Hill, N. Y., 1953)

8 ) R. G. Bowes ; Heat Treatment of Met., 4, 117 (1975) $9)$ N. Birks \& G. H. Meier ; Introd. to High Temp. Oxid of. Met. (Edward Arnold, London, 1983)

10）西山誼行，林 俊雄，小宮宗次，永田文男，市の川竹男,

堤 和男 ; 日本化学会編, 化学総論, №.44 (1984)
11) O. Kubaschewski \& C. B. Alcock; Metall. Thermochem. 5th ed. (Pergampn Press, London, 1979)

12) G. N. Lewis \& M. Randall ; Thermodynamics (McGrawHill, N. Y., 1961)

13) D. R. Gaskell ; Introd. to Metall. Thermdy. (McGrawHill, N. Y., 1940)

14) Y. Jeannin, C. Manneskante \& F. D. Richardson ; Trans. AIME, 227, 300 (1963)

15) A. D. Pelton, 私信

16) A. D. Pelton, H. Schmarzreid \& J. Stricher ; J. Phys. Chem. Solids, 40, 1103 (1979)

17) W. T. Thompson, A. D. Pelton \& C. W. Bale ; Proc. of AI ChE Summer National Meeting (Denver, Colorado, USA, Aug. 28-31, 1976)

18) R. W. Gurry ; Trans. AIME, 188, 671 (1950)

19) R. Littlewood ; JISI, 202, 143 (1964)

20) T. Noda, M. Okada, T. Hirano \& R. Watanabe ; Boushoku Gijutsu, 28, 3 (1979)

21）新居和嘉 ; $D E N K I K A G A K U, 41,(11), 808$ (1973)

22) J. Bénard ; Oxid of Metals, 118, ASM, (1971)

23) E. D. Hondros ; Acta Metall., 16, 1377 (1968)

24) P. B. Sewell \& M. Cohen ; J. Electrochem. Soc., 111, (5), 508 (1964)

25) A. J. Pignocco \& G. E. Pellissier ; J. Electrochem. Soc., 112, 1188 (1965)

26) V. R. Howes ; Corro. Sci., 7, 735 (1967)

27）本間禎一；表面科学，9，(9)，40（1988）

28）吉原一紘, 新居和嘉 ; 日本金属学会誌, 45, (3), 283 (1981)

29）吉原一紘, 新居和嘉 ; 日本金属学会誌，46，(5)，494（1982）

30）新居和嘉, 吉原一紘 ; 日本金属学会会報, 19, (12), 857 (1980)

31) G. C. Wood ; Oxid. Met. , 2, 11 (1970)

32) B. Chattopahyay \& G. C. Wood ; Oxid. Met., 2, 373 (1970)

33) G. R. Wallwork ; Rept. on Prog. in Phys., 39, 401 (1976)

34) G. C. Wood \& F. H. Scott ; Mat. Sci. \& Technology, 3, 519 (1987)

35）三吉康彦，門 智 ; 日本金属学会誌，31，(4)，481（1967）

36) C. Wagner ; Z. Elektrochem., 63, 772 (1959)

37) F. Maak ; J. Electrochem. Soc., 52, (8), 545 (1961)

38) A. Atkinson ; Corro. Sci., 22, 87 (1982)

39) B. D. Bastow, G. C. Wood \& D. P. Whittle ; Oxid. of Met., 16, 1 (1981)

40) R. A. Rapp ; Corro., 21, (12), 382 (1965)

41) A. F Rhines, A. A.Johnson\&W. A.Anderson ; Trans. AI $M E, 147,205$ (1942)

42) Y. Shida, F. H. Scott, B. D. Bastow, D. P. Whittle \& G. C Wood ; Oxid. of Met., 18 (3/4), 93 (1982)

43) D. P. Whittle, Y. Shida, G. C. Wood, F. H. Scott \& B. D. Bastow ; Phil. Mag., 46, (6), 931 (1982)

44) Y. Shida, G. C. Wood, F. H. Scott, D. P. Whittle \& B. D. Bastow ; Corro. Sci., 21, (8), 581 (1981)

45) O. Kubaschewski \& B. E. Hokins ; Oxid. of Met. \& Alloys., 2 nd ed. (Butterworths, London, 1967)

46) C. Wagner ; Corro. Sci., 9, 91 (1969)

47) D. E. Coates \& A. D. Dalvi ; Oxid. of Met., 2, 331 (1970)

48) D. P. Whittle, B. D. Bastow \& G. C. Wood ; Oxid. of Met., 9, 215 (1975)

49) B. D. Bastow, G. C. Wood \& D. P. Whittle ; Corro. Sci., 25, (4), 253 (1985) 
50) T. Narita, K. Nishida \& W. W. Smelzer ; J. Electrochem. Soc., 129, 209 (1982)

51）山崎桓友, 八代利之, 寺島慶一, 井上泰宜 ; 熱処理, 28, (6), 366 (1988)

52）山崎桓友, 八代利之, 寺島慶一; 未発表

53）安原英子, 川崎龍夫, 井 莞爾, 鈴木重治 ; 熱処理, 28, (6), 373 (1988)
54）新居和嘉 ; 金属材料の高温酸化之高温腐食（腐食防食協会 編, 丸善, 1984)

以上参考文献を掲げたが，一般的な合金の酸化については Wallwork (33), Wood\&Scott(34), Rapp(40), Kubaschewski \&Hopkins (45), Birks\&Meier( 9), 新居 (54), およびBastow ら(49), の解説, 著書または論文を参照されたい。 